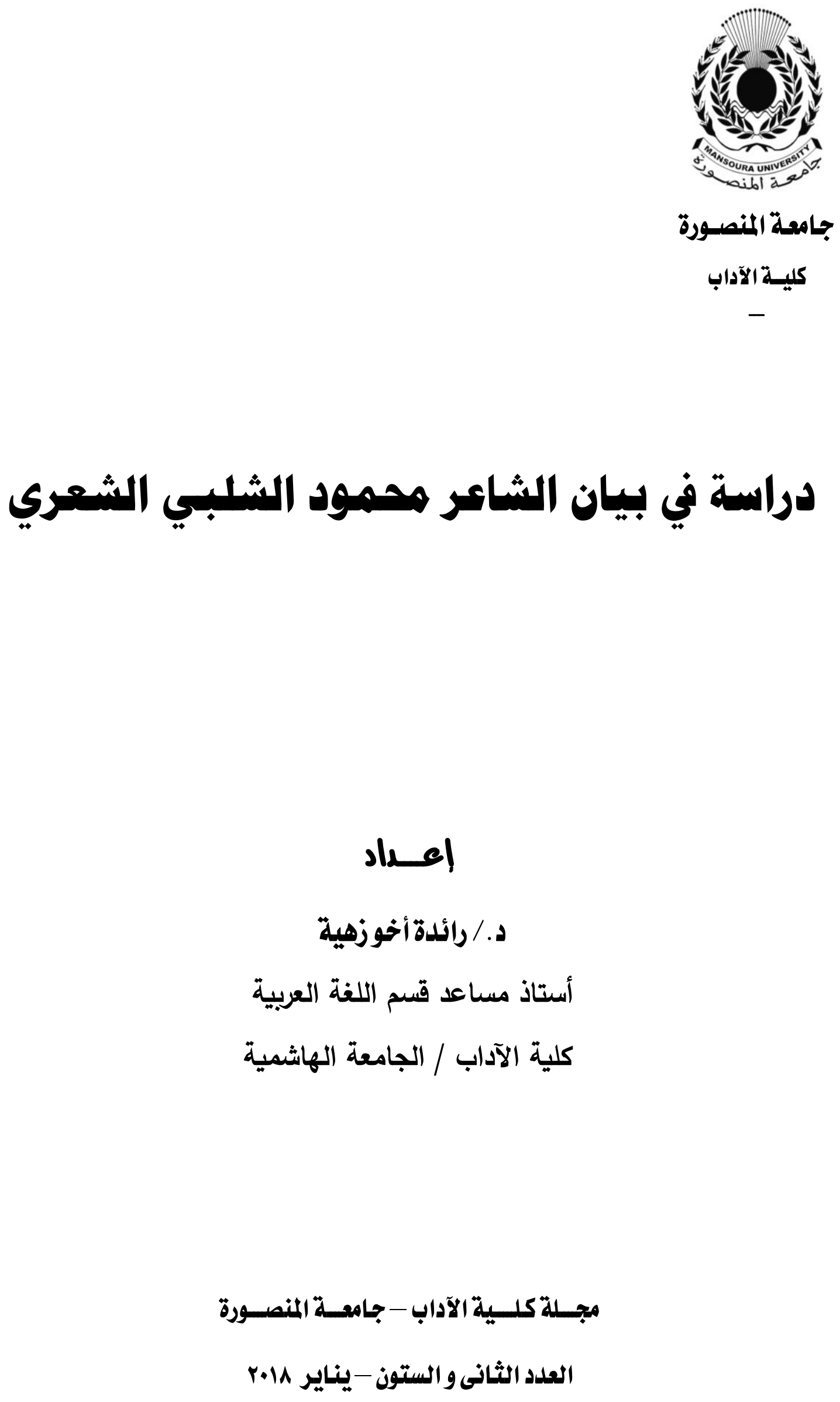




\title{
دراسة في بيان الشاعر محمود الشلبي الشعري
}

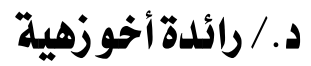

\begin{abstract}
ملخص:

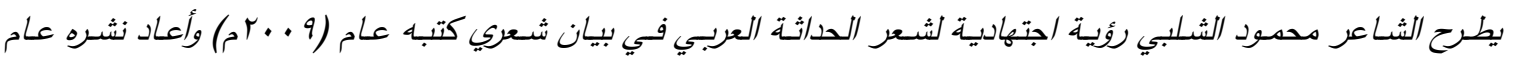

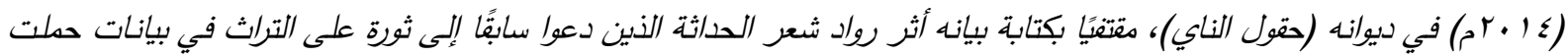

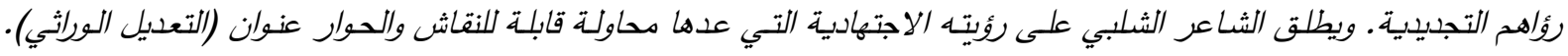

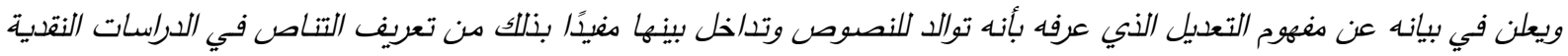

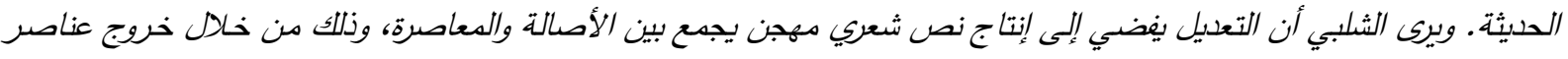

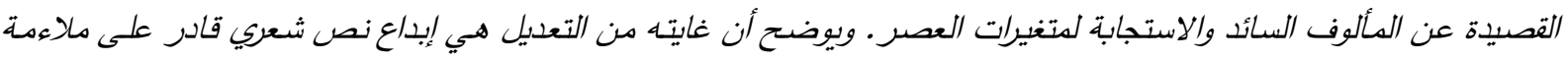

العصر، وإدخال التنوير إلى النص السائد عن طريق الدثاقفة والتتاص الذي بعد أثثرًا من آثار الثثاقفة.

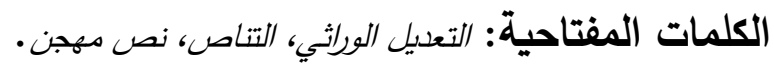

\begin{abstract}
The poet Mahmoud Al-Shalabi presents a jurisprudential vision of the Arab poetry of modernity in a poetic statement written in (2009) and re-published in (2014) in his office (Flute Fields), tracking his writing the impact of the pioneers of modern poetry who had previously called for a revolution on heritage in data that carried their renewed visions. The poet Shalabi calls his jurisprudence, which he considered an attempt to discuss and dialogue entitled (genetic modification). He declares in his statement the concept of the amendment, which he defined as the breeding of text and overlapping between them, thus benefiting from the definition of intertextuality in modern monetary studies. Shalabi believes that the amendment is conducive to the production of a hybrid poetic text combining authenticity and contemporary, through the departure of elements of the poem from the norm and respond to the changes of the times. He explains that the purpose of the amendment is to create a poetic text capable of adapting to the times, and the introduction of enlightenment to the prevailing text by means of culture and intertextuality, which is one of the effects of culture.
\end{abstract}

Keywords: genetic modification, intertextuality, hybrid text.

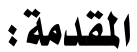

ووظيفتهـ. وكان عـام (9 (9 ام) قد شهر صـدور

أول بيان أدبي نشره نزار قباني في مقدمة ديوانـه

(طفولة نهد)(')، وتوالت بعد ذلك بيانات الشعراء

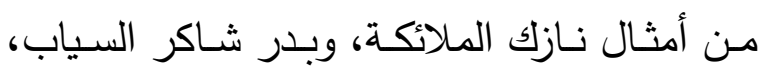

وعبــد الوهـاب البيـاتي، وأدونـيس، و وحمد بنـيس،

وغيرها من البيانات الأدبية التي تحتاج إلى عناية

الباحثين لجمعها ودراستها.

(1) نزار قباني، طفولة نهد، طسז، بيروت، 919 ام، صه-9.
شـهد الوطن العربي بعد الحرب العالميـة

الثانية ظهور وعي جديد يدعو إلى التغيير في

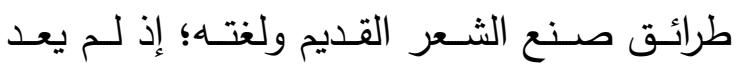

الشعر القديم قادرًا على مواكبة المستجدات. وبدأ

رواد الشعر الحديث بمحاولات قوية في التجديد

فطلعوا علينا بدواوين شعرية ضمنوها قصائد من

الشعر الحر ، اشتملت على مقدمات نثريـة كانت

بمثابة بيانات أدبية موجهة إلى القارئ للإفصاح

عن رؤاهم الجديدة حول مفهوم الشعر وماهيته 
التنظيريـة والثقافيـة المتعدقـة في فهـم العلاقـات الثقافية والاجتماعية(r)(r). عنوان البيان:

بيان شعري

\section{"محاولة في توليد نص شعري مهجن ..."}

يلعب العنوان دورًا في مقاربة النص الأدبي،

ويعد مفتاحًا أساسيًا يتسلح بـه المتلقي للولوج إلى لـى أغوار النص العميقة قصد استتطاقها وتأويلها(؟)؛ وأول مـا يقف عنده القارئ في "بيان شعري" هو العنوان الذي أعلن الثاعر به عن رؤية استشرافية تحمل إرادة في التخلص من نسق فكري قائم إلى نسق آخر ، رغبة في التجديد والحداثة والثورة على

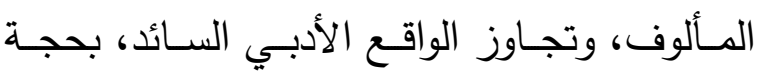
تآكله وترهله، وفقده لأسباب الحياة(0). وإن نظرنـا إلـى عبـارة "بيـان شـعري" مـن ناحية نحوية، فهي خبر لمبتدأ محذوف تقديره هذا؛ أي هذا "بيان شعري"، وإذا نظرنا إليها من وجهة نحـو الـص فإنهـا مبتـدأ معـرف بالإضـافة خبـره الـص المــوازي "محاولـة في توليـد نـص شـعري مهجن ..." الذي ألحقه الثـاعر بالعنوان لـ "يمثل

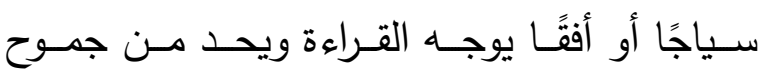
التأويل، من خـلال مـا يسـاهم في رسمه من آفاق

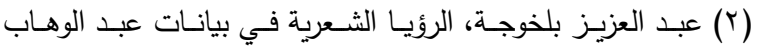

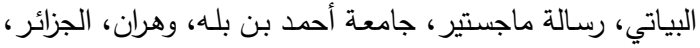

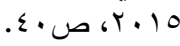

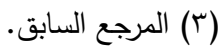

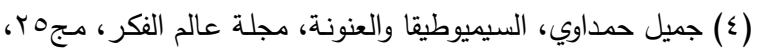

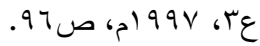

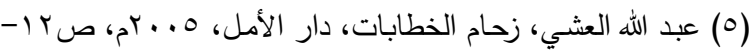

وسـيتناول هذا البحـث بالدراسـة والتحليـل

البيان الثـعري للشـاعر الأردني محمود الشلبي، الـي كتبـه أواخـر عـام (9 . . بم)، ونشـره في صـحيفة الدسـتور الأردنيـة عـام (· ( • (rم)، ثم أعـاد نشـره فـي ديـوان (حقــول النـاي) الـذي الذي

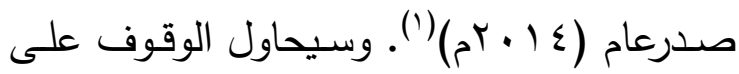
رؤيـا الثـاعر الاجتهاديـة في البيـان مـن خـلال دراســة لغــة البيـان وعنوانــه، ومفهـوم التعـديل الـوراثي، وعناصـر القصـيدة المعنيـة بالتعـديل، وآلياته، والغاية منه.

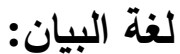
اتخذ الثاعر الشلبي من لغة الشعر وسيلة

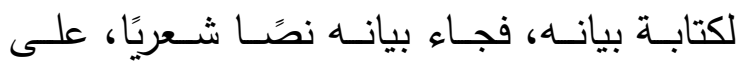
خـلاف بيانـات سـابقيه مـن الثـعراء المعاصـرين لحركـة الحداثـة الثـعرية، الـذين جعلـوا بيانـاتهم خطابـات نثريـة في قضـايا شـعريـة. وإذا كـان الشعراء المعاصرون قد سعوا من خلال بياناتهم النثريـة إلى زلزلـة قناعـات المتلقين، ومـراوغتهم، وإقتاعهم، فـإن الشلبي لـم يكتف بذللك، وأراد أن يتجـاوز مخاطبـة العقل إلى مخاطبـة كل كيـان المتلقي؛ مخاطبة عقله ووجدانه وروحه وجسده، وتغييـر ذوقـهـ. وأراد الثـاعر أن يفنـد عبـارة أن الشاعر ما هو إلا مبدع فقط، ويفتح لذاته حريـة اقتحام فضاء النقد والتظير ، محاولًا خلق نموذج في الكتابـة والإبـداع الشـعري منطلقًا مسن ذاتهـ وتجربته، فكتب بيانًا شعريًا جمع فيه بين الكفاءة

(1) محمـود الثـلبي، شـعر حقول النـاي، دار اليـازوري، عهـان، . 
ملفوظات سابقة في ملفوظ لاحق، وعرفه باختين

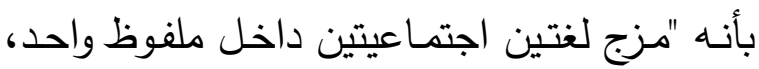

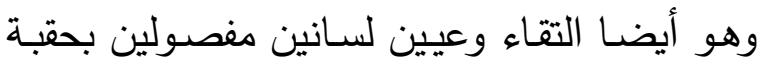
زمنيـة، وبفـارق اجتمـاعي، أو بهمـا معـا، داخـل ساحة ذلك الملفوظ"(0). وجعل باختين التهجين أو التفاعل اللفظي

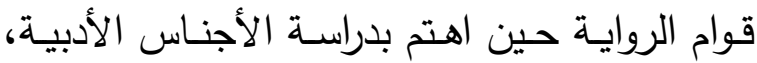
وتوصل إلى أن الجنس الأدبي من خلال التفاعل

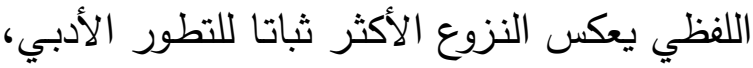

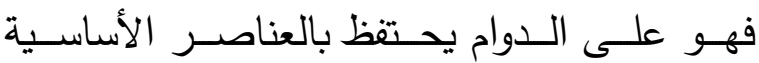

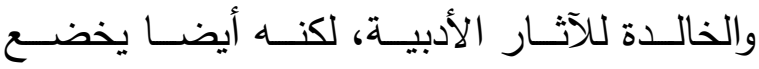

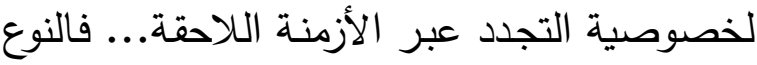
الأدبي - حسب باختين - يعيش في الحاضر لكنه دوما يتذكر ماضيه وأصوله. إنه يمثل الذاكرة(7).

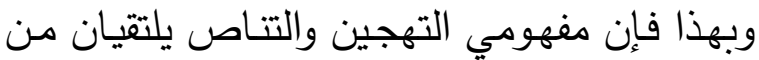

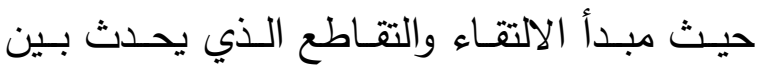
الخطابـات واللغنات والتراكيب المتنوعـة في نص

$$
\text { جديد لاحق زمنيا. }
$$

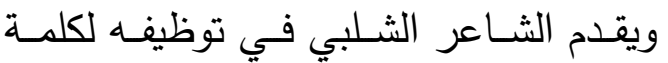

التهجين في العنوان رؤيـاه الاجتهاديـة التي يرى

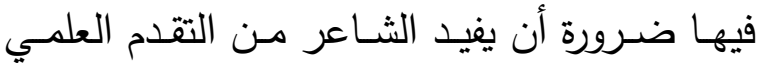

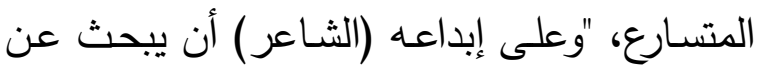

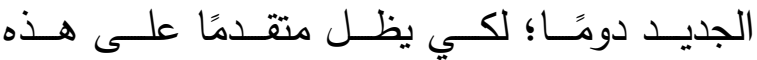
التكنولوجيات ذات القدرة الفائقة على إعادة إنتاج

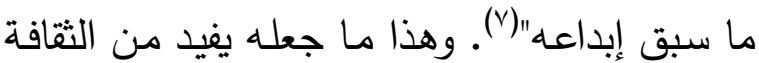

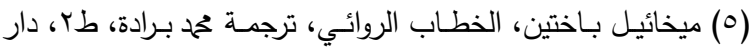

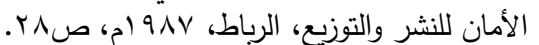

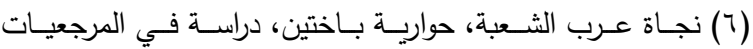

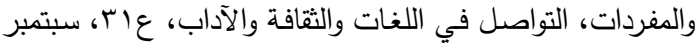

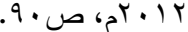

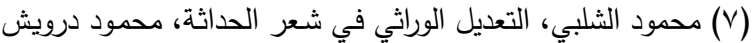

انتظـار محددة"('). ويكشف النص الموازي أن

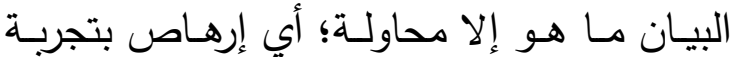
جديدة في توليد (إنتاج) نص شعري، والتجربة التهان

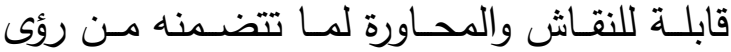

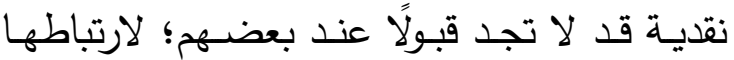
بالحداثة والخروج عن المألوف (†). وتكثــف كلمـة (توليـــ التـي اسـتخدمها الثلبي في عنوانه الموازي عن مضمون البيان، فهو توليد نص من نص آخر ؛ فالنص الشعري لا يمكن أن يكون نصًا برينًا ونفيًا؛ إذ "لا وجود

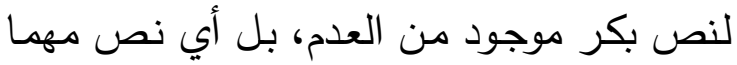

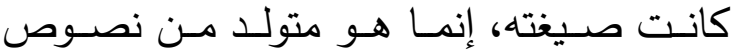

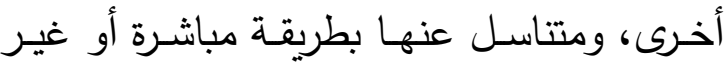

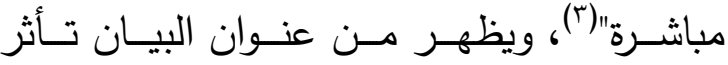
الثـاعر بمفهوم التتـاص عنـــ الدارسـين الـذين يرون في عملية التناص تتاسلًا وتوالدًا وتعديلًا، وإعادة نمذجة النصوص القديمة التراثية وتكرارها لارتباطها بالسلف ولقوتها الإيجابية(؟). وحـد الثـاعر في عنوانـه الهـوازي آليـة

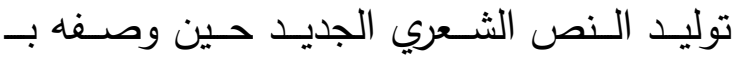
(مهجن). وتحيل هذه الآلية القارئ على مفهوم

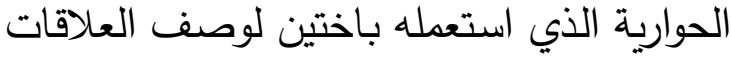

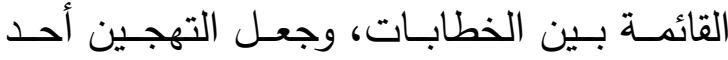
مظاهره؛ إذ يعمل على تحديد أسـاليب حضور الفطاتين وجدي

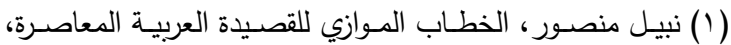

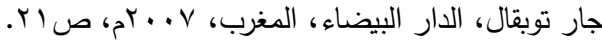

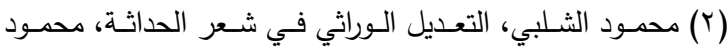

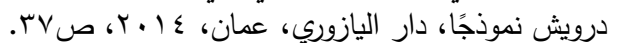
(r) طانية حطاب، التهجين النصي في ظل نظريـة التـاص، مجلة

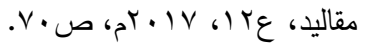

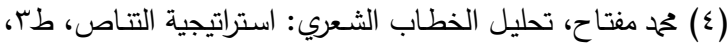

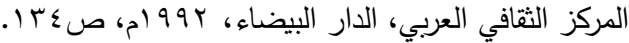


والتعديل وراثيًا يعني أيضًا ما يأتي:

أن يُولد نصٌ آخر من نص آخر (0).

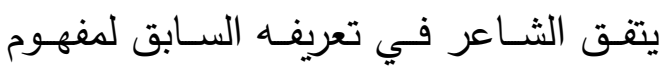
التعديل الوراثي مـع دارسي مفهوم التتاص الذين

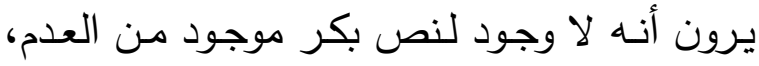

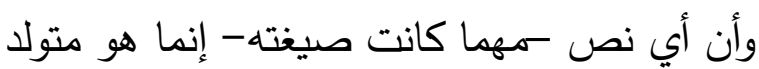
عن نصوص أخرى، ومتتاسل عنها بطريقة مباشرة

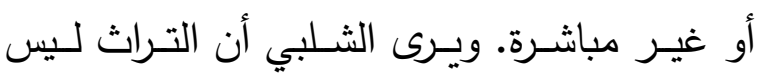

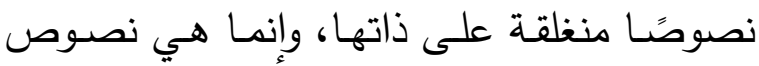
سابقة تتفاعل وتتناسل وتتمازج مع نصوص لاحقة

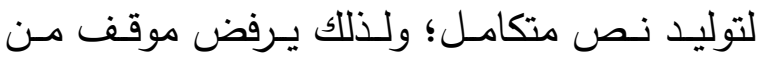
يدعون إلى "الانفصـال عن التراث، والبدء مـن فـن نقطة بعيدة عنه.. من حداثة لا تتنمي إلى القديم.. تتجاوزه ولا تعيد صياغته، بل تطرح بدائل جديدة

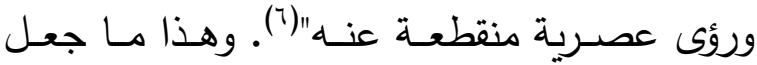
الثـاعر يـدعو إلـى الإفـادة مـن الثقافـة العلميـة والتكنولوجيا التي "تغري الثـاعر بتطوير أدواتـه

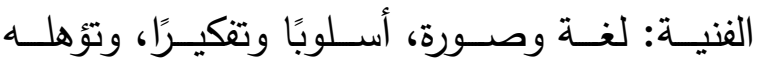
لاسـتيعاب روح العصـر والتعـايش مـع مسـتجداته ومتطلباتــه، ضــــن حركـــة التــاريخ والتـــراث والمجتمع"('). واستجابة لهذه الدعوة افتتح الثلبي

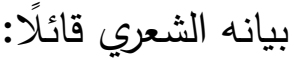
الجينات لها في الشعر مسارات ومسارب، تعبرها حاملة للشعر صفات الأجناس،

(0) محمود الثلبي، شعر حقول الناي، ص. • 17.

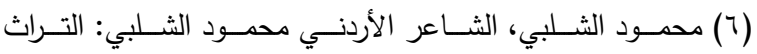

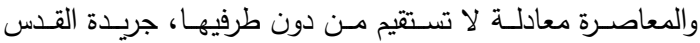

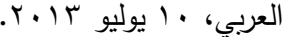
(V) محمود الشلبي، التعديل الوراثي في شعر الحداثة، محمود درويش (V)

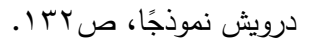

العلميـة للعصـر محساولًا أن يحدث مقاربـة بـين العلم وعملية الإبداع، فاستعار فكرة التهجين من الهندسـة الوراثيـة. فكمـا أن البـاحثين في مجـال

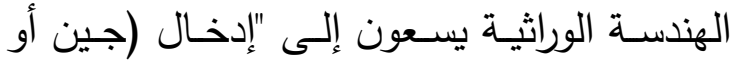

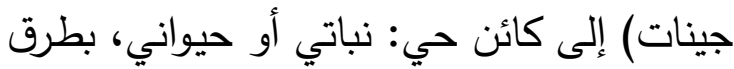
تكنولوجية، وذلك بأخذ صفات جديدة مرغوبة من كائن ونقلها إلى الكائن الحي المراد تعديله وراثيًا،

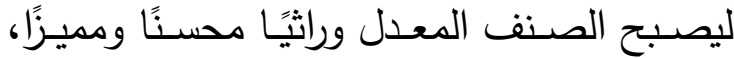

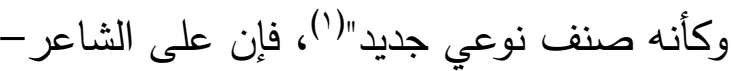
كمـا يـرى الثـلبي- أن يسـى إلـى إبـداع نص

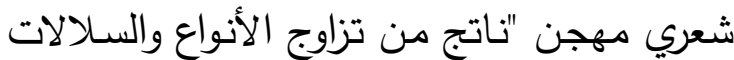
والأصــناف المختلفــة بفعـل المثاقفـــة والتــأثر والتأثير "(r)، يكون وراثيًا، و : حداثي المبنى والمعنى...

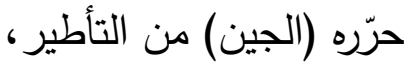
وأدخله في التتوير (r)، مفهوم التعديل الوراثي: - ماثي أطلق الثلبي على محاولته في توليد نص

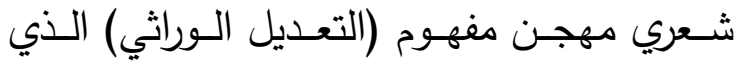
قصد به إعادة إنتاج نص جديد دون التجرد من الماضي، وبما يلائم العصر ، وإيجاد نص شعري يربط الماضـي بالحاضـر، والتـراث بالمعاصـرة، باعتبارهــــا "معادلــة متكاملــة لا تصــح بـدون طرفيها" (ई). وعرف الثاعر التعديل الوراثي قائلًا:

(1) نفسه، ص 1 (1)

(Y) نفسه، ص 10 (Y)

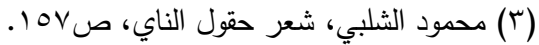

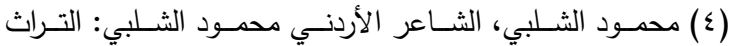

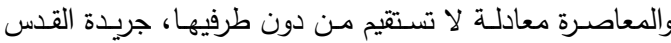

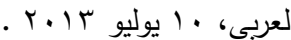


يحاول من خلالها أن يقنعه بفلسفته، على أن يبين للمتلقي عناصر القصيدة التي يجب التعديل فيها وآلية التعديل.

عناصر القصيدة المعدلة: أولًا: التعديل في لغة الشعر الشعرا عرف الثاعر التعديل قائلاً: فالتعديل المقصود هنا يتضمن ما يأتي: توليد المعنى البكر من اللفظ البكر .. إزاحات وإضاءات،

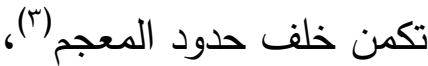
عنـي الثـعراء منــذ القـديم بينـاء القصـيدة

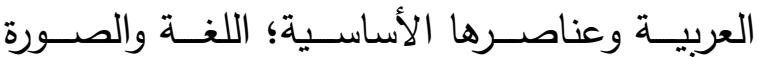
والموسـيقى، وحين دعـا رواد الحداثـة إلى الثورة على القديم ركزوا في دعوتهم على لغة القصيدة

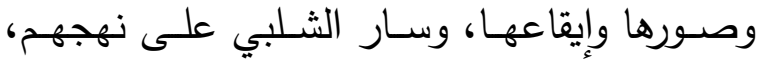
فارتأى أن تجديد الثعر وجعله ملائمًا للعصر لن يحدث إلا بالتوليد الذي عرف أنه "إبداع لدلالات معجمية وتراكيب دلالية جديدة ... ويرتبط بظهور معنى جديد أو قيمة دلالية جديدة بالنسبة لوحدة

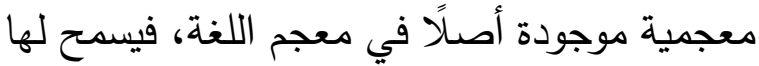
ذلك بالظهور في سياقات جديدة لم تتحقق من قبل"(|). وبالتوليد يستطيع الشـاعر أن يبني كيانًا لغويًا جديدًا يحمل معان بعيدة عن المعجم اللغوي

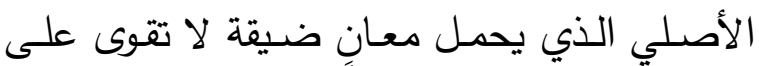
نقل الحقيقة وملاءمة العصر ، وإيجاد لغة شعرية جديـة تكـون دلالاتها أعمـق وأوسـع مـن خـلال

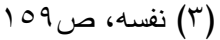

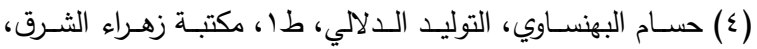

فتتعش الكلمات(').

يوظف الثـاعر العلم في بيانه، ويفيد من الهندسة الوراثية في علم الأحياء ليحدث مقارنة بين الكائن الحي والقصيدة المعاصرة؛ فإذا كانت الجينات في عالم الأحياء تنقل خصائص كائن حي إلى كائن آخر عند التهجين، فإن القصيدة

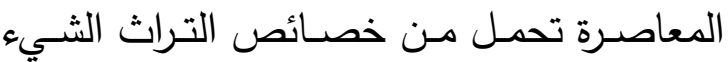
الكثير • ويؤدي التقاء السابق/ التراث مع اللاحق

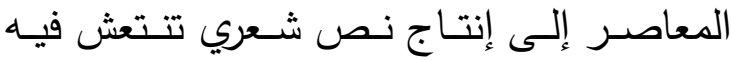
الكلمات. يقول الثاعر: الحرف بميسمه الفطري يُهجَّن في النص، يُعَدَّل من (بكتيريا) نافعة، ... لنبات. ليؤول على صدر الصفحة فاكهة طيبة،

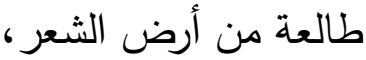
ومن وحي الشرفات(؟).

فـالحرف الذي هـو أسـاس الكلمـة يهجن ويعدل؛ أي تبقى أصسوله ثابتـة وتحـول الأجزاء

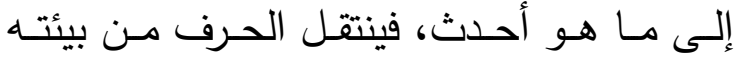
الأولى إلى بيئة جديدة لإنتاج نص جديد شبهه

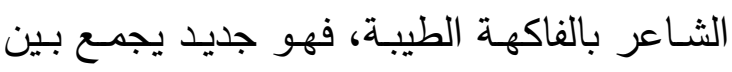
الماضي وأصالته والحاضر وعصرنته.

عناصر التعديل الوراثي: - (التي أراد الثلبي من مشـروعه الاجتهادي في لفي

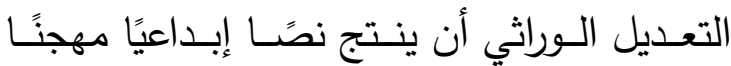

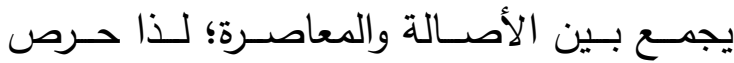
الثـاعر في بيانـه، الذي يعـد رسـالة للمتلقي، 
الثاعر ويذيبها في سياق إبداعي تتطلبه القصيدة

وتجربة الشاعر الخاصة، وتصبح جزءًا منه"("). وعند تتبع تجربة محمود الثلبي الثعرية في "بيان شـعري"، يتبين للقـارئ أن الثـاعر استطاع استيعاب ثقافة العصر العلمية، وإبداع نص شعري يجمـع بـين العلـم ومصـطلحاته دون التتـازل عـن شـعرية الـص، يقـول الشـلبي في قصـيدة "بيـان

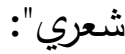
والشعر تعدله المرأة والمرآة، ووجه التأويل، وفاتحة المتعة، فيما يفرزه العشق من النتح الوجداني، أو التمثيل الضوئي،

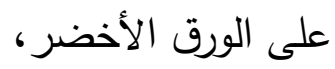
تحت لعاب الثمس المنساب، بنُسنغ الشجر الطالع في الأوقات(£). عندما يتحدث الثـاعر عن تعديل النص الشعري وإنتاج نص شعري جديد عصري، يستثر

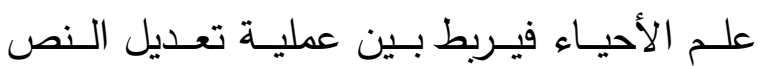
الشعري وعملية التمثيل الضوئي؛ فإذا كانت عملية البناء الضوئي تقوم نهارًا على تحويـل الطاقـة الكهرومغناطيسية إلى طاقـة كيميائية لتصنيع الغذاء الـلازم لنمو النبات، فإن عمليـة تعديل النص الشـري ترتكز على تحويـل

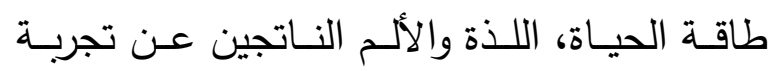
العشق، إلى طاقة شعرية من خـلال استخدام لغـة
الإيحاء لا الإيضاح، ومن خلال الجوهر الروحي للألفــاظ لا الثـكل، وبـذلك تتحـرر اللغــة "مـن النمطية التقليدية، ومن قيود الاستعمال المبتذل، ومـن موروثهـا الشـفهي إلـى لغــة جديـدة معدلـة

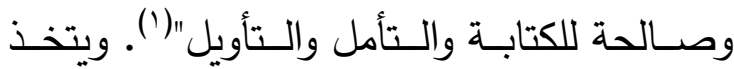
الثاعر من الانزياح والانحراف عن قانون اللغة وسـيلة لخـرق المعجـم اللغـوي السـائد، وتوليـد دلالات جديدة بعيدة عن الدلالات المتداولة غير القادرة على التعبير عن تجارب معاصرة. ولم يكتف الثـاعر بخرق المعجم اللغوي الســائد لتجديــد الثـعر ، فـربط الثـعر بـالخبرة والتجربة، وعرفه قائلًا: والثعرهوالشعر ، فحل اللغة المشحونة بالخبرة، والمصطلحات(r). ارتبط مفهوم الشعر عند القدامى بالنظرة الشكلية (الـوزن والقافيـة)، وتأثر عند المحدثين بثقافاتهم المختلفة واتجاهاتهح النقدية المتباينة بين محسافظ على القديم وثائر عليـه، وجـاء تعريـف الشـعر عند الشـلبي نابعًا مـن رؤيـاه التي تدعو إلـى التعـديل والتجديـد، فـربط الثـعر بتجربــة الشـاعر المتجددة التـي تجعلـه قـادرًا على خلق عــل إبــداعي تكـــون لغتــهـ قـادرة بــدلالاتها وإيحاءاتها على نقل مـا يعيشـه الثـاعر ويثـعر بـه، وقـادرة على اسـتيعاب روح العصـر ، وتقبـل "الحقـائق العلميـة ومصــلحاتها التـي يمتصــها 


$$
\text { وخي أفق الرئيا، }
$$

دعا الثاعر في "بيان شعري" إلى الانزياح

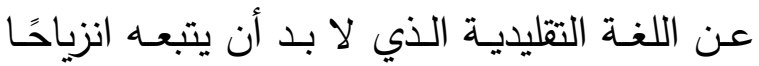

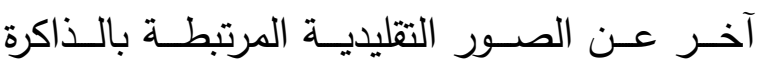
التراثية، ويرى الثلبي أن تجديد الصورة وتعديلها مرتبط برؤيا الشاعر التي تعد "أداته الوحيدة التي لئي

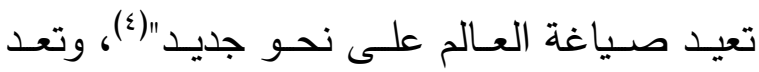

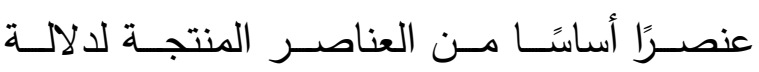

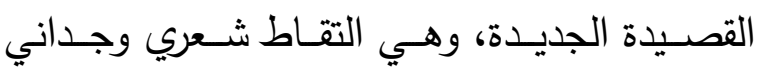
للعالم يتجاوز الظاهر إلى الباطن، ويتجاوز حدود العقل وحدود الـذاكرة والحس، ليكثـف علاقـات

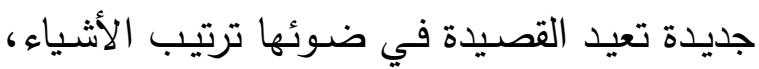
وخلق عـوالم جديدة تتصـهر فيها تجربـة الثـاعر باعتباره مبدعا، وتجربـة المتلقي باعتباره مشـاركا

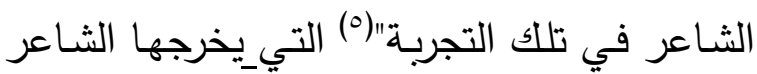
إلى الوجود عن طريق الصورة.

تسـهم التجربـة الثـعرية في تثـكيل رؤيـا الثاعر الخاصة، ويسعى الثاعر إلى التعبير عن تلك الرؤيا من خـلال الصسورة، ولمـا كانت الرؤيا الثـعرية متغيرة ومتعددة بتجدد التجربـة الثـعرية

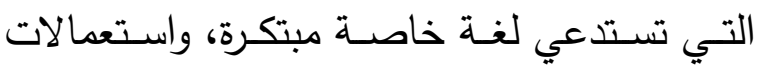
لغوية غير موجودة، فإن الصور الفنية المعبرة عن

( )

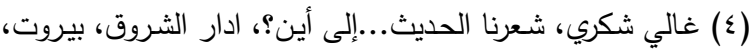

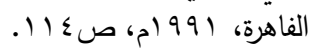
(0) أحمد الطريسي، التصوير المنهجي ومستويات الإدراك في العمل العل الأدبي والشعري، الطربي، الشئ
شعرية جديدة خارجة عن المعجم اللفظي السائد، يستلههمها الثـاعر مـن تجربتهـه الخاصـة والبيئة المحيطة بـه، فينتج نص جديد لا يشبه غيره، لهنه

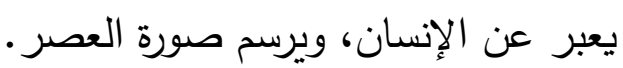
وهكذا يتبين أن العلاقة بين الثعر والعلم

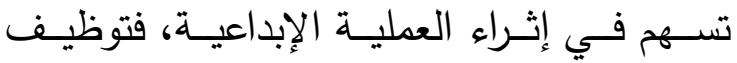

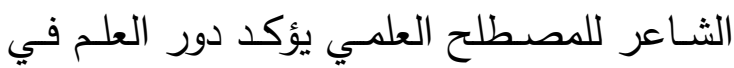

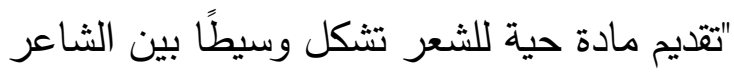
وعملـه الإبـداعي، وهذه نقلـة نوعية في تطوير القصيدة وتعديلها، وفي توظيف المعلومة العلمية

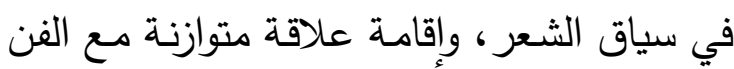

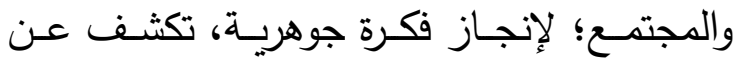

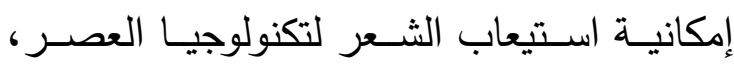

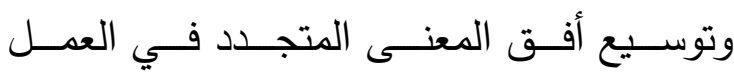
الإبداعي" (1) (1) ثانيًا: التعديل في الصورة عرف الثاعر التعديل الوراثي قائلًا: فالتعديل المقصود هنا يتضمن ما يأتي:

$$
\text { رسم الصورة من رحم الرؤيا، }
$$

وفي مقطع آخر من البيان أكد على ما سبق فقال: والتعديل وراثيًا يعني أيضًا ما يأتي:

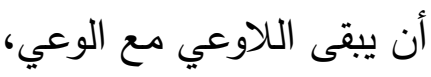
تبحث عن معنى المعنى...

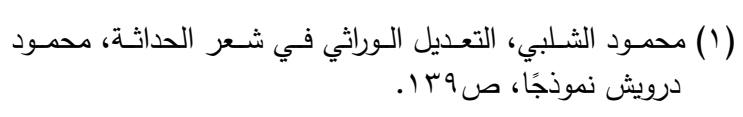

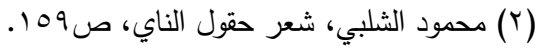


من إحداث تعديل في الموسيقى قادر على "ربط إيقاع العصر بإيقاع الماضي، والاحتفاظ بطاقته وقدرته على التأثير في المتلقي، وزيـادة استجابته لروح الثعر والعصر معًا"('). رابعًا: التعديل في المضمون

عرفت القصيدة التقليدية بأغراضها الشعرية الثابتة؛؛ إذ لـم يخرج الثـعراء عن حديث الطلل، ووصف الصحراء ومشاق الرحلة، ومن ثم الانتقال

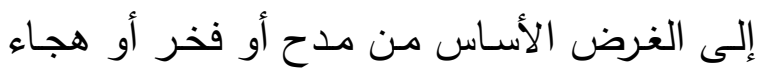
أو غزل، وكان الثـاعر العربي بذلك يوثق حياته بطريقة سطحية ظاهريـة لا عمق فيها، ولما كان الثاعر الثلبي يدعو في بيانه إلى التعديل على لهى كل موروث لا يلائم العصر ولا يعبر عنه، كان لا لا لاعي لئل

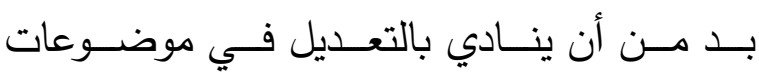
القصيدة. يقول الثاعر في المقطع الرابع من بيانه

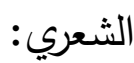

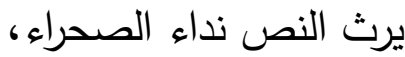

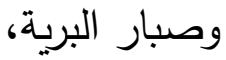

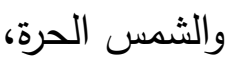
والطلل الملتاع على فقد المرأة، والغزوة تلد الغزوة،

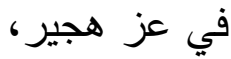
وتوهج آل في الفلوات.

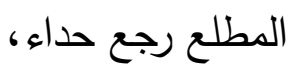
والمقطع قافلة... وقفت عند حدود الذات().

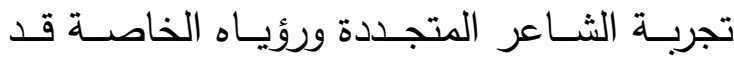
تعددت، وسـعى الثـاعر إلى استحضـار صـور

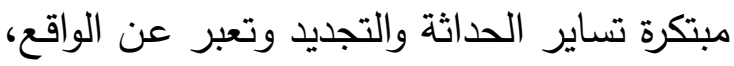

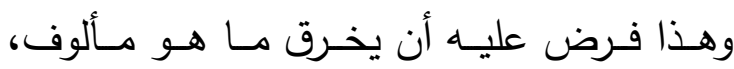
ويتجــاوز الصــور البدائيــة المرتبطــة بالــاكرة التراثيـة، ويسـتحدث صــورًا تقـوم علـى دلالات جديدة من خلال تحريك الخيال والانزياح للتعبير عن تجاربه الجديدة وملاءمة العصر . ثالثًا: التعديل في الموسيقى التخدي ثـار الثـعراء الحـاثيون على الموسـيقى التقليديـة حين وجدوها غير قادرة على التعبير عن علاقة الثاعر بالواقع المتغير ؛ لذا كان لا لا لهان بد من إيجاد موسيقى تنسجم دع هذا الواقع، وقد كرر الثلبي دعوة الثعراء الحداثيون حين دعا إلى إجراء تعديل في الموسيقى فقال: سأُعَدَّلُ ما شَنْتُ وراثياً.... في الشَّْرْ .. ومَنْهجها..

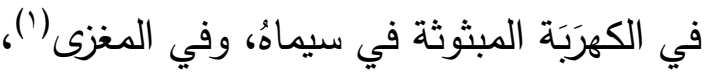
ويعلن الثاعر في مقطع آخر من "بيان شعري" عن سبب هذا التعديل قائلًا: والتعديل وراثيًا يعني أيضًا ما يأتي: تبحث عن معنى المعنى... عن نص تتماهى فيه الموسيقى،

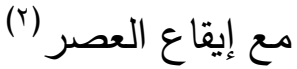
دعا الثاعر إلى توليد نص شعري جديد

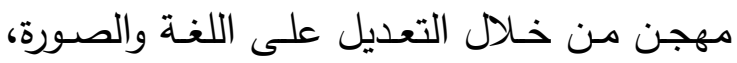
ولما كانت الموسيقى مرتبطة باللغة، كان لا بد 
والطيرُ تُناجيه بأجنحَة لَهَهى.... (r) كان الثاعر العربي يعبر عن حالة الوجد التي يعيشها عند رحيل محبوبته، وشعور الوحدة

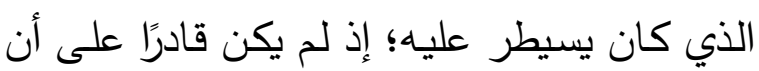

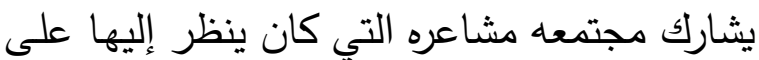

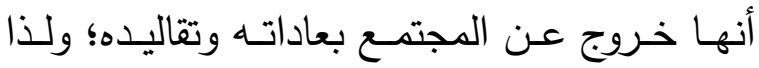
اتجه إلى البيئة من حوله يوظف معطياتها للتعبير عن قضاياه، فلم يجد غير الريح يحملها أشواقه لمحبوبته، ولم يشعر معـه سوى طيور الصحراء

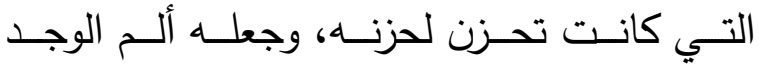
والحرمان يشعر بالوحدة والعزلة. ولم تكن الدحبوبة وألم فراقها السبب الوحيد بألم الثاعر وعزلته، فإن بان ظلم البشر وغدرهم ولاسيما الأقارب كان سببًا آخر بهذه العزلـة التي جعلته يتخذ مـن الحيوان مـرة

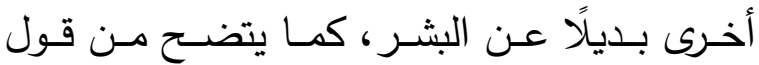
الثلبي: - (الثي

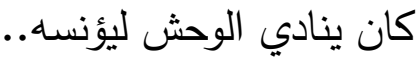

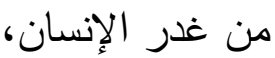

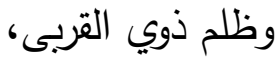

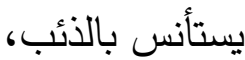

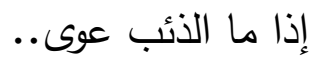

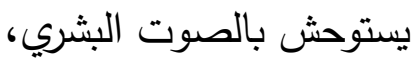

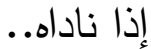

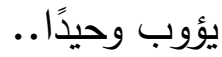
لخباء ضربته الريح، وصلى فيه الغيم مقيمًا... وتوارى خلف ندي الصبوات(؛).
يبدأ الثاعر مقطعه السابق بالفعل (يرث)

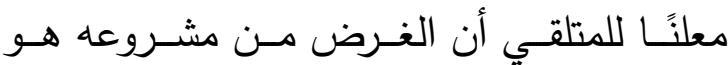
التعديل الذي يحافظ على الأصل ويحول الأجزاء

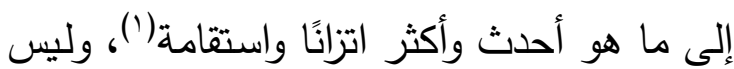
الغاية من مشروعه الاجتهادي الثورة والانفصال عن الماضي. ثم يعرض للموضوعات التي اعتاد القدامى على النظم فيها، ولم تخرج عن الذاتية

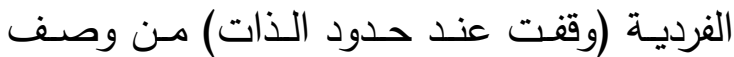
للصحراء والطلل والحرب.

كان الثاعر القديم يتخذ الثعر وسيلة للتعبير عن واقعه، كما يتضح من قول الثلبي:

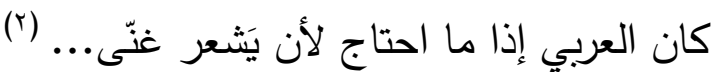
مشـيرًا إلـى علاقــة التوأمسـة بـين الثــر الثر والغناء؛ فمنذ القديم كان الثـاعر يخرج أفراحسه وآلامه أصواتًا يلحنها تلحينًا يمثل مشاعره سميت شعرًا. وكان الثعر أكثر ما يوظف في التعبير

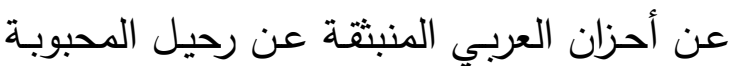
التي كان الشاعر لأجلها، كما يقول الثلبي:

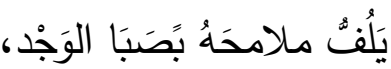

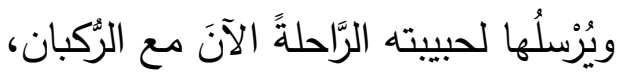

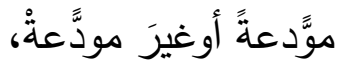

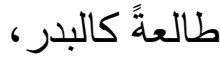
إلى كَرْقَى هَوْدجها...

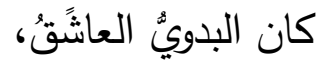

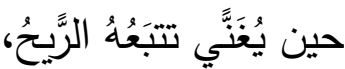

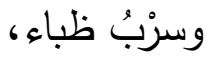

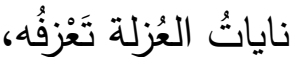


استعبدهم، واستعان بهم الشلبي ليوضتح للمتلقي ما عناه بالتعديل الوراثي، فقال: كان عبيد الشعر يربون قصائدهم كالخيل، الخيل لها أيضا.... أصل وسلالات (؛).

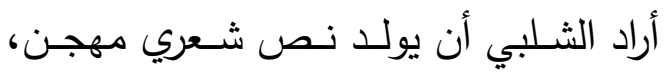
وأن يبين للمتلقي آلية ذلك، فعرض لمدرسة عبيد الثـعر وشـبه عنـايتهم بأثـعارهم بعنايـة العربـي بخيله. إذ يعد الخيل موروثًا ثقافيًا، اهتم العربي بها حتى ألفوا كتبًا في أنسابها للحفاظ عليها، والشعر عنــد العربـي مــوروث ثقــافي يحمـل ســمات وخصـائص لا بـد مـن المحافظـة عليها وتلقيحهـا بسمات جديدة مستوحاة من العصر ليظل الثـر قادرًا على القيام بوظيفته التي ارتضـاها لـه العربي منذ الأزل، وهي التعبير عن قضـايا عصره، وكان هـا مـدعاة للتجديـد والتعـديل في بعض الـنص الشعري الوراثي، كما وضـح الشـاعر بقوله بعد أن استعرض مشاهد من حياة العربي: سأعدل في ضوء المعطى... بعض مقاطع،

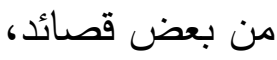
من بعض حروف ومعانيها،

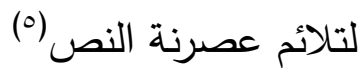
إن اقتصـار الثـاعر التعديل على (بعض مقـاطع ...) انتقــاء واعٍ مـن موضــوعات الثـعر القديم يجعل التركيب الجديد المعدل ليس خلطًا

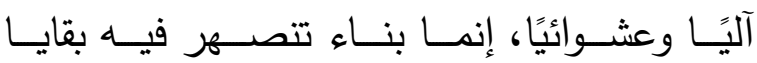
النصـوص القديمـة بطريقــة واعيـة، تجعـل الـص
يوظـف الثـلبي الثـعر القـديم، فيتــاص نصـه السـابق مسع شكوى طرفـة الاجتماعية مـن قسوة أهله وغلظتهم قائًاً: وظلم ذوي القربي أثد مضاضة من وقع الحسام المهند (1) ويستحضر قول الأحمير السعدي عندما نفر من أخيه الإنسان: عوى الذئبُ فاستأنستُ بالذئبِ إذ عوى وصوَتَّ إنسانٌْ فكدتُ أطيرُ (r)

يعرض الشلبي للمشـاهد السـابقة من حياة العربـي ليوصـل للمتلقـي فكرتـهـ مـن التعـديل؛ فالطريقة التي كان يعبر بها العربي عن ذاته، والأدوات التـي كـان يتوسـل بهـا لـذلك، لـم تعـد ملائمة لعصرنا الذي يشهد تغيرات مستمرة؛ ولذا كان على الثـاعر المعاصر أن يتجاوز الطريقة التقليديـة إلى طريقـة معاصـرة تجعله قـادرًا على السير في ركاب التجديد والتطور •. ولمـا كـان الثـاعر القـديم يثـعر بأهميـة الشعر في تطهير نغسه، وتخليصها من آلامها، فقد عُني بتنقيح شعره وتغييره وتبديله حتى يطلع به على قومه، يقول الثلبي: كان العربي إذا ما احتاج لأن يشعر غنى... وإذا ما ابتدع الشعر تأنى.... ومـن هنـا، ظهـرت مدرسـة عبيـد الثـعر الذين اسـتفرغ الثـعر جهدهم في تهذيبـه حتى

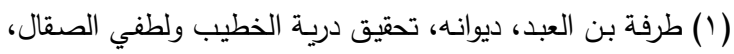

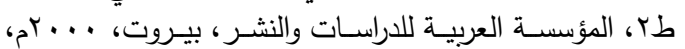
صن מ מ

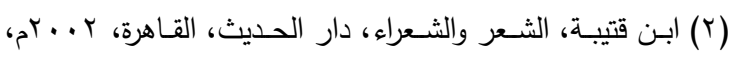
جr (r) محمود الشلبي، شعر حقول الناي، صـ صـا. 
الثعر ؛ لذا جعل التعديل يطـال بعض الثـعر لا

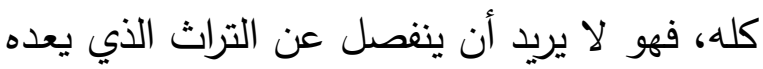

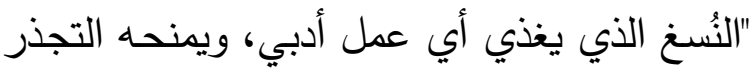

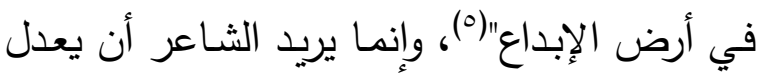
بعض هذا التراث ويخضعه لكل جديد حتى يصبح قـادرًا على التعبيـر عـن روح العصـر، وتصـوير

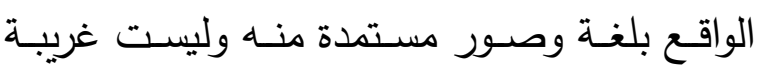
عند.

وفي مقطع شعري آخر من البيان، يكثف الثلبي عن سبب التهجين قائلاً:

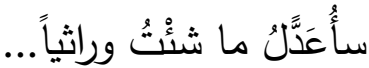
ليجيء النسل وراثيًا....

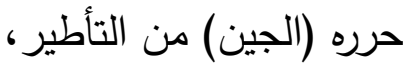

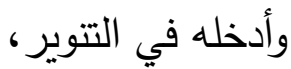

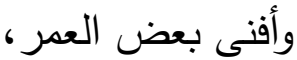
ل أجل مثاقفة ذات دلائل،

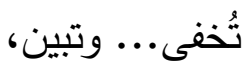
وتحفل بالتلوين. وتتابع في النص تناصًا..

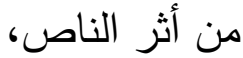
وتدخل عولمة الحاضر والمستقبل، في ظل المستثمر ع.... والمستعمر ... والمحتل (7).

دعا الثلبي في "بيان شعري" إلى التعديل في اللغة من خـلال الانزيـاح عن المعجم اللفظي
الجديــــالمهـن ملائئَا للعصـر الـذي أنتجـه، وقادرًا على التعبير عن قضـايا العصر وهمومـهـ

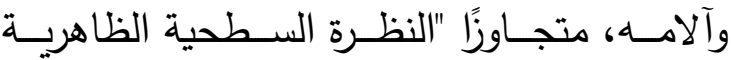
والمعنى الثابت إلى دلالات متغيرة، ومستويات جديدة ومتعددة للمعـاني، بمـا يمكن أن ينـدرج

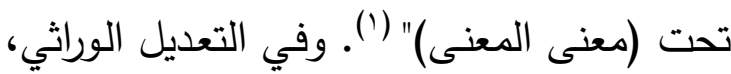
وظفت الرؤى، والأحـام، والصـور ، والإيقاعـات

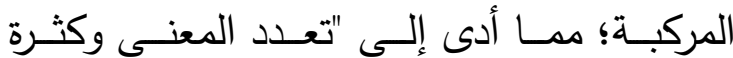
الإيمـاءات التأويلية، وإشـراك المتلقي في تذوق التها النص الثعري وتحليله وتأويله في قراءة واسعة" تكثـف عمـا في الـص مسن معـان وتعالقـات نصية"(r) الغاية من التعديل الوراثي: - النية يرى الثـاعر الثلبي أن التغيير والتطوير التطائ في الثـعر مـ "استحقاقات القصيدة الحداثيـة،

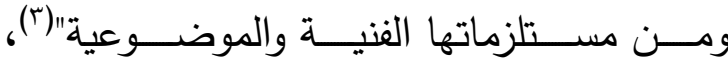
وأن على الثـاعر أن ينساق دائيًا إلى التغيير؛

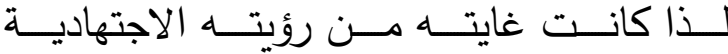
(التعديل الوراثي) عصرنة النص، - لم عدلت النص وراثيًا؟! - ليلائم هذا العصر (£). فقد أراد الثـاعر أن يعدل النص الثـعري لهري

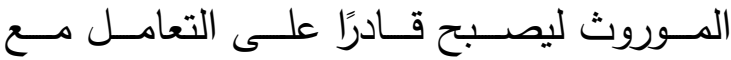
المتغيـرات الثقافيـة الجديدة في عصـرنا، وفي لئي الوقت نفسـهـ أراد أن يبقـي التـراث حاضـرًا في لجي

$$
\begin{aligned}
& \text { (1) محمود الثلبي، التعديل الوراثي في شعر الحداثة، ص.r. }
\end{aligned}
$$

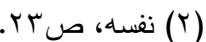

(0) محمـود الثـلبي، الثـاعر الأردنـي محمـود الثـلبي: التــراث والمعاصرة معادلة لا تستقيم من دون طرفيها.

(T) محسود الثـلبي، الثـاعر الأردنسي محمـود الثـلبي: التـراث والمعاصرة معادلة لا تستقيم من دون طرفيها. (£) محمود الثلبي، شعر حقول الناي، صن درن طرنيا. 
ناتج عن المزج بين حضسارتين أو ثقافتين وليس خضوع ثقافة لثقافة أخرى.

ولما كان الثلبي يسعى في مشروع التعديل

الوراثي إلى توليد نص من نص آخر بالمحافظة

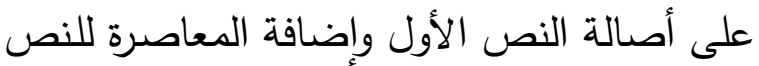
الجديد، فقد تبنى مصطلح المثاقفة بمعنى المزج والتحـاور بـين الثقافـات ولـيس الخضــوع والتنكر

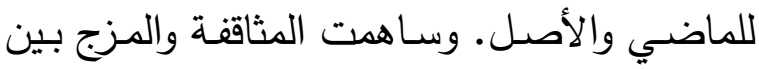
الحضارات والثقافات بظهور مفهوم التتاص الذي يعد أثرًا من آثار المثاقفة، وعامل إغناء إضـافة

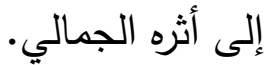

ترى جوليا كريستيفا أن 'كل نص هو عبارة عن لوحة فسيفساء من الاقتباسات، وكل نص هو

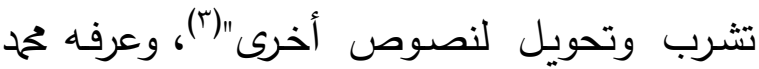

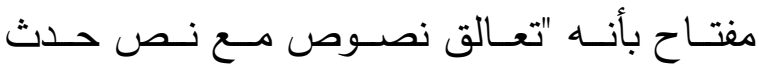

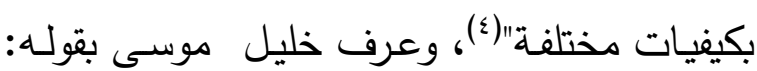

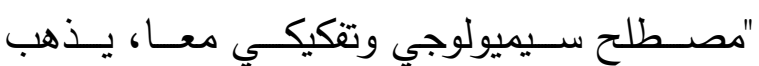

Julia أصـابه، وفي مقدمتهم كريستيفا

، Genette وجينيت Barthes وجيتيكت إلى أي نص يحتوي على نصوص كثيرة، نتذكر

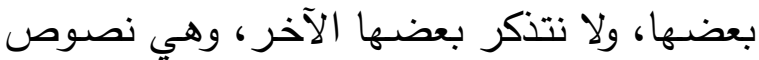

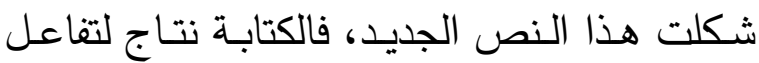
عدد كبير مـن النصـوص المخزونـة في الذاكرة القرائية، وكل نص هو حتمـا نص متتـاص، ولا وجود لنص ليس متداخلا مع نصوص أخرى"(().
المألوف، ورأى أن استخدام مصطلحات العصر العلمية والثقافية يسهم في التعديل والخروج باللغة

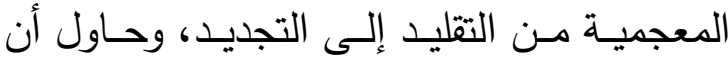
يطبق رؤيته الاجتهادية في التعديل في إبداعها

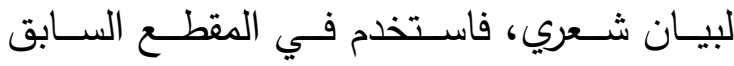
المصطلحات الثقافية التالية (التنوير ، المثاقفة،

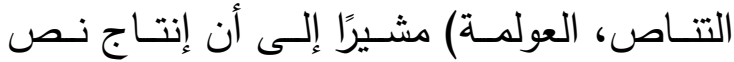

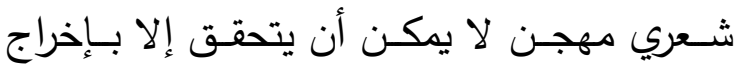

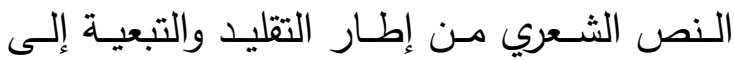

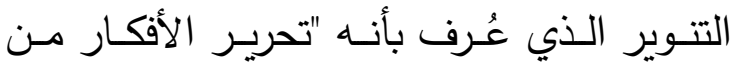
صنميتها، والإنسـان من استلابه في الفكرة"(()، بإحداث ثورة فكريـة لا تتتكر للماضي ولا تمجده

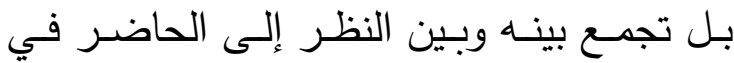
مضمار الثقافة والعلوم والتمدن في الغرب. ومن

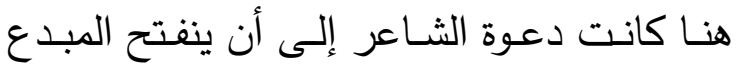
على الثقافـات الأخـرى ليكتسـب ثقافــة مغـايرة لثقافته الأصـلية تمكنهـه مـن أن يحدث تلاقحًا

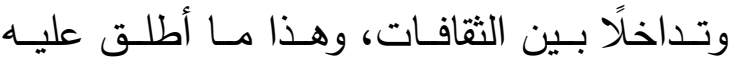
الدارسون مصطلح المثاقفة.

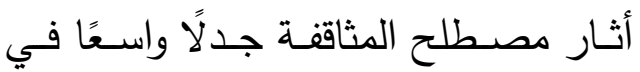
العالم العربي، إذ يراه بعض الدارسين غزوًا ثُقافيًا

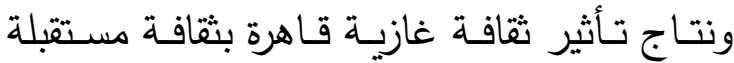
مقهورة، ويراه آخرون تحاور ومقارنـة بين ثقافة جديدة تم اكتسابها اختياريًا وثقافة أصلية لدى

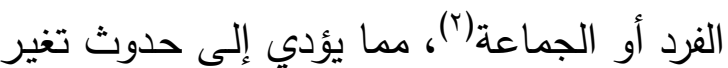

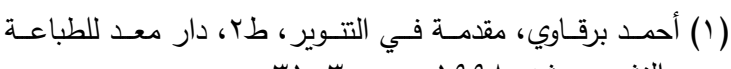

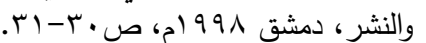

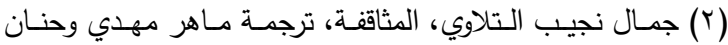

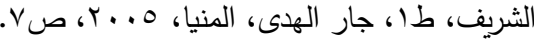


النصـوص وتتوالد وتتجدد ويحدث التعديل الذي

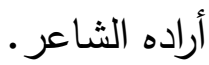

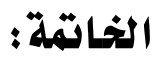

حاول الثـاعر محمود الثلبي أن يقدم رؤية اجتهاديـة لمفهوم الثـعر الحـداثي تربطـهـ بالبنيـة الوراثية للشعر العربي، أطلق عليها مفهوم التعديل

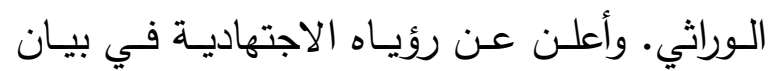
شعري، كما فعل سـابقوه من رواد شعر الحداثة. وبعـد دراسـة البيـان توصـل البحـث إلـى النتـائج

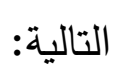
1- رؤيا الثاعر الاجتهادية والموسومة بالتعديل

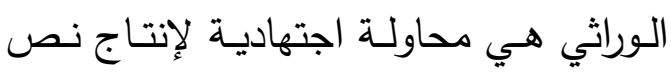
شعري مهجن من خلال التوالد والتداخل بين لإناتين

$$
\text { النصوص. }
$$

r- التعديل الوراثي يحرص على ثبات الأصل

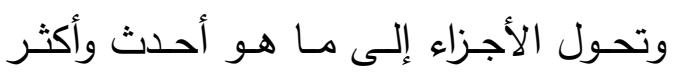
اتزانًا واستقامة.

بـ - التعديل يحـافظ على العلاقـة بـين التراث/

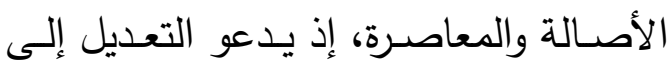

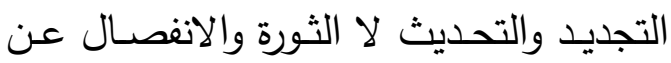
الماضي. ع - التعديل الوراثي يشمل عناصر القصيدة من

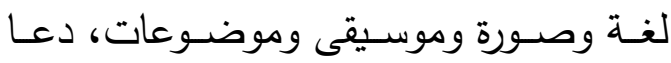
الشاعر إلى الخروج بها عن المألوف السائد والإطار التقليدي إلى حداثة تلائم العصر .

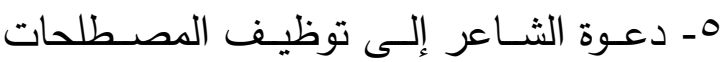

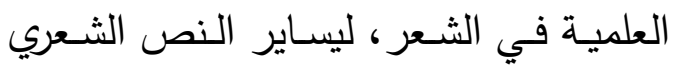

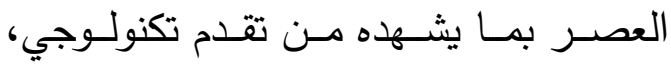
وليكون قادرًا على التعبير عن هذا العصر.
فالتناص بتوليد نص من نصوص أخرى، يعمل على التعديل والتجديد في النصـوص السـابقة

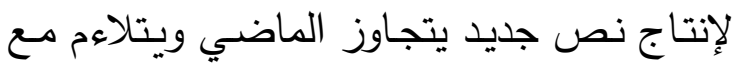

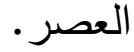
ويظهـر مـن تعريفـي المثاقفـة والتتـاص السابقين أن هناك تداخلًا وتقاربًا بينهما كما يقول محمد مفتاح. ويبرز التناص الذي يوظفه المبدع لإيصسال مغزى أو تثبيت فكرة، العنصر الثقافي الذي "يغذي النص ويجمله، ويعبر عن الانفتاح

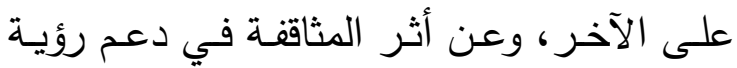

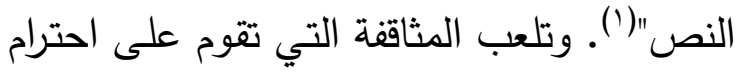

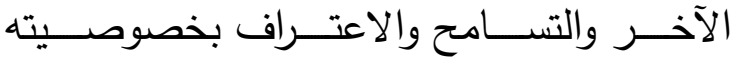
واختلافه، دورًا في مواجهة العولمة التي تحاول

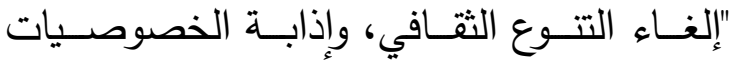
الثقافية، وتتميط الثقافة بجعلها واحدة شاملة ذات الفاه

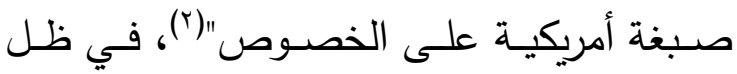
خضوع العالم العربي للهيمنة الاقتصادية والثقافية والعسكرية من الآخر القوي، وتسهم في الوقت

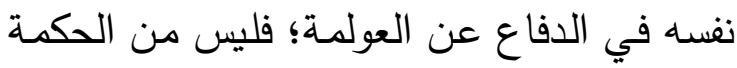
أن يظل العربي ينظر إلى العولمـة على أنها

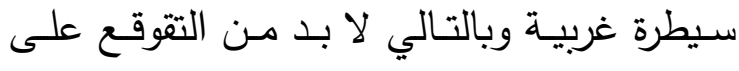
التراث، بل لا بد أن ينظر إليها على أنها رؤية لـانية

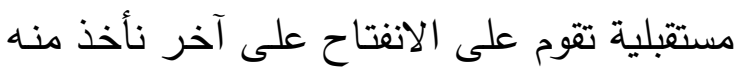

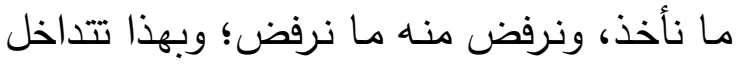

(1) سـحاب شـاهين و جودت إبـراهيم، التــاص في روايـة المسـتقع

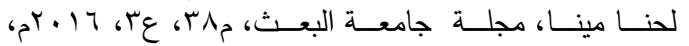

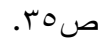
(ץ) العولمة وتأثيرها على الثقافة العربية، انظر الرابط الإككترني: https://crimedz.blogspot.com/2017/06/globalization .Impact.Arabic.culture.html 
0- جوليا كريستيفا، علم النص، ترجمة فؤاد الزاهي، طا، دار توبقال، الدار البيضاء،

$$
\text { •p) } 991
$$

7- حسام البهنساوي، التوليد الدلالي، طا،

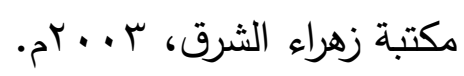

V- خليل الموسى، قراءات في الشعر العربي الحديث المعاصر، منشورات اتحاد الكتاب

$$
\text { العرب، دمشق، . . . بم. }
$$

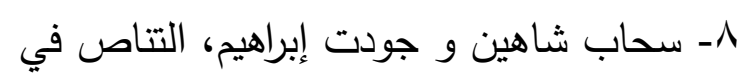
رواية المستتقع لحنا مينا، مجلة جامعة

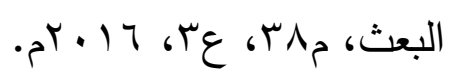

9- طانية حطاب، التهجين النصي في ظل

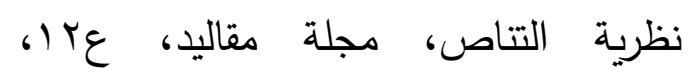

$$
\cdot{ }^{2}+1 \mathrm{~V}
$$

• ا- طرفة بن العبد، ديوانه، تحقيق درية

الخطيب ولطفي الصقال، طب، المؤسسة العربية للدراسات والنشر ، بيروت، . . ب م.

ا ا - عبد العزيز بلخوجة، الرؤيا الشعرية في بيانات عبد الوهاب البياتي، رسالة ماجستير، جامعة أحمد بن بله، وهران،

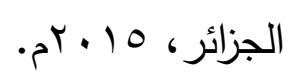

r ا - عبد الله العشي، زحام الخطابات، دار

$$
\text { الأمل، } 0 \text {. . بrم. }
$$

ץ - - غالي شكري، شعرنا الحديث...إلى أين؟،

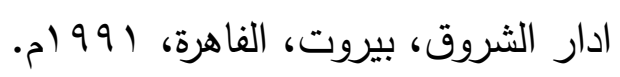
ع ا ـ ابن قتيبة، الشعر والشعراء، دار الحديث،

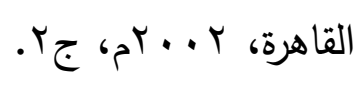

آ- الغاية من التعديل الوراثي هي إنتاج نص شعري قادر على ملاعمة العصر · V- تلعب المثاقفة دورًا في توليد نص شعري مهجن مـن خـلال الانفتاح على الثقافـات والحضارات الأخرى.

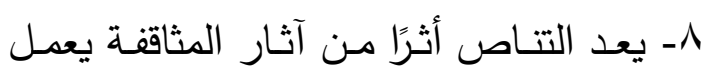
على توليد نص شعري مهجن من خـلال التداخل والتلاقح والتوالد بين النصوص. 9 ـ أفــاد الثـاعر مـن المصـــلحات الثقافيـة (التنوير ، التتاص، المثاقفة، العولمـة)، ولم يقدم جديدًا في مشروعه على ما دعا إليه الحداثيون مـن قبل، عدا دعوته المستمرة

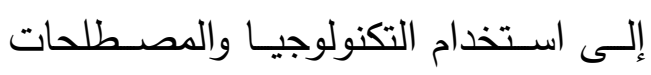
العلمية في إبداع النص الشعري الجديد. • (-مشـروع الثـاعر الثـلبي (التعديل الوراثي) يبقى -كمـا قـال - محاولـة اجتهاديـة قابلـة للحوار والمناقشة.

المراجع: ا ـ أحمد برقاوي، مقدمة في التنوير ، طب، دار معد للطباعة والنشر ، دمشق 991 (م. r- أحمد الطريسي، التصدير ومستويات الإدراك في العمل الأدبي والشعري، شركة بابل للطباعة والنشر، إلهرئ

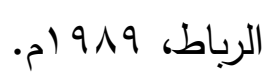

r- جمال نجيب التلاوي، المثاقفة، ترجمة ماهر مهدي وحنان الشريف، طا، جار

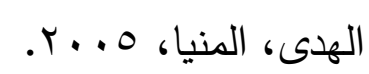
ـ- جميل حداوي، السيميوطيقا والعنونة،

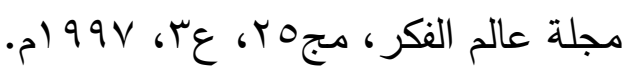


1 - محمد مفتاح، تحليل الخطاب الشعري: استراتيجية التتاص، طب، المركز الثقافي العربي، الدار البيضاء، ب99 (م. 1 ا - محمود الشلبي، شعر حقول الناي، دار اليازوري، عمان، ع أ بrم.

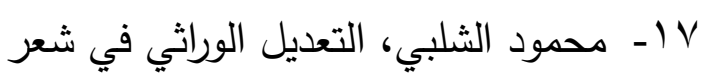
الحداثة، محمود درويش نموذجًا، دار

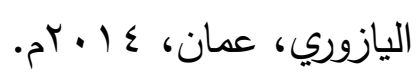
11 ـ ـ محمود الثلبي، الثاعر الأردني محمود الشلبي: التراث والمعاصرة معادلة لائل تستقيم من دون طرفيها، جريدة القدس

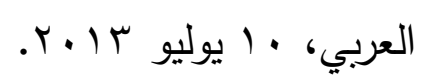
9 1 - ميخائيل باختين، الخطاب الروائي، ترجمة حمح برادة، طب، دار الأمان للنشر

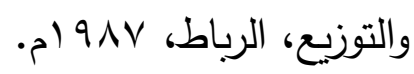

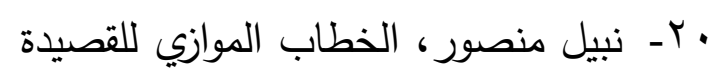
العربية المعاصرة، جار توبقال، الدار البيضاء، المغرب، V V. . Yم. ا Y- نجاة عرب الشعبة، حوارية باختين،

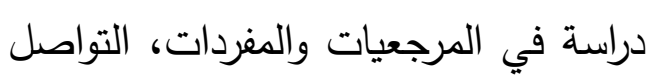
في اللغات والثقافة والآداب، عاس،

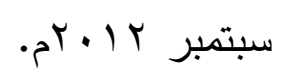
r r- نزار قباني، طفولة نهد، طس ب، بيروت، . $) 9 \wedge 9$ 